Copyright (C) 2021 The Author/s

This work is licensed under a CC-BY 3.0 License

Peer review method: Double-Blind

Accepted: August 24, 2021

Published: September 21, 2021

Original scientific article

DOI: https://doi.org/10.47305/JLIA2137102g

\title{
THE ASSESSMENT OF FISCAL DEFICIT ON ECONOMIC GROWTH IN TRANSITION COUNTRIES OF SOUTH-EASTERN EUROPE
}

\author{
Luljeta Gllogjani \\ Faculty of Economics, University of Prishtina "Hasan Prishtina", Kosovo \\ ORCID iD: https://orcid.org/0000-0002-9519-0390 \\ luljetagllogjani@gmail.com \\ Driton Balaj* \\ Faculty of Economics, University of Prishtina "Hasan Prishtina", Kosovo \\ ORCID iD: https://orcid.org/0000-0002-5532-2184 \\ driton_balaj@hotmail.com
}

\begin{abstract}
The overall aim of this research is to observe the impact of fiscal deficit on economic growth in the transition economies of South-eastern Europe. The fixed-effects and dynamic linear regression were used to carry out this revision. The data used in this revision are quantitative data annually and cover the period 2005-2019. The outcomes detect that there is a confident and statistically important effect among the fiscal deficit and economic growth for the transition economies of Southeast Europe, supporting the Keynesian theory. Furthermore, the outcomes of this research show that public debt to GDP, foreign direct investment in GDP, exports, and imports in GDP have an important effect on economic growth. Findings have shown that public debt and imports have a positive influence on economic growth, unlike exports and foreign direct investment, which showed an adverse effect on economic growth. Moreover, for other additional factors, the inflation rate, the employment rate, and the real interest rate, the results of the study do not show any significant consequences on economic growth. The research also contributes in the macroeconomic aspect to the opening of discussions among the relevant stakeholders, including those coming from the policy-making area.
\end{abstract}

Keywords: Economic Growth; Fiscal Deficit; Panel Data; Fixed-Effects; Dynamic Linear Regression

\section{INTRODUCTION}

A fiscal deficit occurs when a government spends more than it collects on taxes and other revenues in a given time. The impact of the fiscal deficit on economic growth is one of the most debated topics in all world economies. Keynes is the first to predict the importance of the fiscal deficit as an instrument of economic growth, in his General Theory (Keynes 1936). 
Keynes proposed that the fiscal deficit could increase the recession. In a recession, private sector expenses fall, as well as savings rise, which in turn lead to unused resources. Government borrowing is one way of exploiting these unused savings and the 'start' of the economy. Deficit spending can help promote advanced growth, which will enable higher tax revenues to be generated and thus reduce the fiscal deficit over time (Navaratnam and Mayandy 2016).

As for the effects of fiscal deficit on economic growth, academic and empirical revisions showed a confident, adverse and neutral impact. Conferring to Abdullah et al., (2018), the obvious differences in the findings are expected not only because of the stage of development in which each country is positioned but also the way the country addresses the problem of fiscal deficit financing. The issue is further important for developing economies than for the developed ones as they always have a targeted level of growth as part of their development policy. In addition to foreign assistance, it requires a steady growth in domestic spending from a government perspective to realize and maintain the targeted growth in those countries.

Although there are a large number of empirical studies inspecting the association between fiscal deficit and economic growth, little academic research has been conducted on the transition economies of Southeast Europe. Therefore, this study becomes necessary to better recognize the connection between fiscal deficit and economic growth for these countries, as little has been done in this regard. The overall purpose of this study is to examine the influence of fiscal deficit on economic growth in the transition countries of Southeastern Europe. To achieve this goal, the study has identified the following objectives: a) empirical research on the association between fiscal deficit and economic growth, and b) empirical research on the association among public debt, foreign direct investment, trade opening, employment rate, inflation rate, the real interest rate, and economic growth.

Research questions:

- How fiscal deficit affects economic growth?

- How do public debt, foreign direct investment, trade opening, employment rate, inflation rate, the real interest rate affect economic growth?

Research hypothesis:

- $\mathrm{H}_{0}$ : There is a negative association between fiscal deficit and real GDP growth

- $\mathrm{H}_{1}$ : There is a positive association between fiscal deficit and real GDP growth

The dependent variable in this research is the gross domestic product (GDP), an indicator of economic growth. Independent variables are fiscal deficit, public debt, foreign direct investment, trade opening, inflation rate, employment rate, and real 
interest rate. Although the fiscal deficit variable is the focus of the study, other variables are also used to achieve better results. This study contributes to the fiscal plan literature by reviewing the association between fiscal deficit and economic growth from an empirical effort focused on transition countries in Southeast Europe. Fiscal deficit and economic growth are highly debated topics in developed and developing economies. Therefore, the need for this type of knowledge is of great importance, as one of the government's priorities is to inspire and promote a sustainable level of growth.

\section{LITERATURE REVIEW}

Theoretical Literature

On the impact of fiscal deficits on economic growth, there are three main schools of thought.

\section{Keynesian Theory}

According to Keynesian theory, fiscal deficits serve as a means of improving the economy and impacting social welfare. This approach argues that there is an adverse association between fiscal deficit and unemployment, as well as a confident link between fiscal deficit and real growth (Dritsakis and Stamatiou 2016). From the Keynesian perspective, government spending will have a multiplier effect on output and employment. Increased spending will grow total demand in the economy, which improves the profitability of domestic investment and leads to advanced investment. Overall, higher government spending will have a confident effect on the pace of economic growth (Ramu and Gayithri 2016). So, government spending is an important component of Aggregate Demand (AD) in the economy. Whenever AD falls short (through recessions), the government can raise spending, which in turn will increase the $A D$, and in turn, inspire the economy (Hussain and Haque 2017). According to Thornton (1990), the Keynesian view of deficit spending in the macroeconomy is that it may be able to reduce fluctuations in economic activity due to gaps between savings and investment caused by exogenous changes in investment. From this perspective, deficit spending was seen as both desirable and necessary to offset the cyclical fluctuations of economic activity that were characteristic of capitalist, free-market economies.

\section{Neoclassical Theory}

Conferring to Neoclassical theory, there is a negative association between fiscal deficits and economic growth. Fiscal deficits increase overall lifetime consumption by shifting taxes to subsequent generations. If economic resources are fully used, increased consumption necessarily means maintaining savings. Interest rates need to be raised to 
bring equilibrium to equity markets. Thus, persistent deficits "crowd out" the accumulation of private capital (Bernheim 1989). Any intensification in government borrowing raises the interest rate, which negatively distresses private investment, which in turn affects the growth rate. High external borrowing to fill the investment gap negatively affects the exchange rate and the trading account, which again adversely affects the growth rate (Ramu and Gayithri 2016).

\section{The Ricardian Equivalence Hypothesis}

In the Ricardian perspective, fiscal deficits are seen as neutral in terms of their growing impact. Deficit budget financing comes only through tax deferrals (Mohanty 2012). Barro (1989) presented this reverse approach as the Ricardian Equivalence Hypothesis (REH). Ricardian equivalence, or Barro-Ricardo equivalence proposition, is an economic theory that advocates that government fiscal deficits do not distress the overall level of demand in an economy (Eigbiremolen et al. 2015). From a Ricardian perspective, a decline in administrative savings resulting from the fiscal deficit is offset by an increase in private savings, leaving national savings and, therefore, investment unchanged. In this case, there is no change in the real interest rate. Proponents of this view have confidence that a fiscal deficit represents future trade taxes for taxes today. That is, if the government spends more than it taxes today, it should tax more than it spends tomorrow. Once people understand this correlation, they will spend and save accordingly. As a result, the fiscal deficit has little or no impact on economic growth (Navaratnam and Mayandy 2016). Given the different roles of the above different approaches in the literature, some of the empirical studies in these areas are highlighted below.

Empirical Literature

Empirical studies that focused on the issue of fiscal deficit and their consequence on economic growth, showed a positive effect, a negative effect, or no effect in this relationship. Consistent with the Keynesian view, the positive effect of fiscal deficit on economic growth showed some of the empirical studies: Kryeziu and Hoxha (2021); Taylor et al. (2012); Akosah (2013); Adam and Bevan (2005); Abdullah et al. (2018); Ahmad et al. (2020) and Onwioduokit and Inam (2018).

Kryeziu and Hoxha (2021), using a panel data model for a period from 1995 to 2015, on the effect of fiscal deficit on economic growth for Eurozone economies, showed that the fiscal deficit to GDP ratio is statistically significant with a positive effect. Taylor et al. (2012), using quarterly data for the period 1961-2011 (first quarter), examined the relationship between primary fiscal deficit (total deficit minus interest payments), fiscal debt, output growth rate, and interest rates in the US. The econometric 
results verified the countercyclical response of the primary deficit to growth and further showed that a higher deficit stimulates faster growth, with GDP growth.

Akosah (2013) examined the threshold effect of fiscal deficit on economic growth in the case of Ghana, using quarterly data from 2000-2012. The study found a long-term inverse relationship between fiscal deficit and economic growth, especially as deficits are often used to finance recurrent expenditures, suggesting that the high budget deficit, driven by recurrent expenditures, slows economic growth. In the short term, however, the author found that the fiscal deficit stimulated economic growth, but a deficit beyond the 4 percent of GDP threshold was found to be damaging to economic growth. Adam and Bevan (2005) examined the relationship between fiscal deficit and economic growth in 45 developing countries during the period 1970-1999. The findings show that a deficit threshold of $1.5 \%$ is essential for economic growth. Furthermore, there is evidence of gaining growth to reduce deficits at this level and the effects disappear within a fiscal regulation. Abdullah et al. (2018), including 40 years of time series data covering the period from 1975-1976 to 2014-2015, have examined the impact of the fiscal deficit on economic growth. The findings showed that the fiscal deficit would have a positive impact on economic growth as long as it is considered long-term, and since the error correction terms were insignificant, it is argued that the short-term dynamics between the fiscal deficit and economic growth for the Bangladeshi economy are missing. Threshold values that were calculated remained within the range of 4.5 to 5 percent of GDP. Any amount of spending that exceeds that level would have a disadvantageous effect on economic growth.

Using data from 1980 to 2017, Ahmad et al. (2020) examined the links between fiscal deficit and economic growth in Malaysia and applying the OLS model, the findings showed that the fiscal deficit has a positive influence on GDP and that a higher fiscal deficit stimulated the economy through the 1997-98 and 2008-09 economic crisis periods. Onwioduokit and Inam (2018) investigated the relationship between fiscal deficits and economic growth in Liberia using the OLS model, their results showed that there is a long-term relationship between fiscal deficit and economic growth, and there is also a positive and significant relationship between fiscal deficit and economic growth. Based on the authors' calculations, a 1 percent increase in deficits is associated with an increase of approximately 0.42 percent in economic growth.

Consistent with the Neoclassical view, the adverse effect of fiscal deficit on economic growth showed some of the empirical studies: Zoto and Berisha (2016); Todorova (2019); Bokemeier (2015); Tung (2018); Goher et al. (2012); Nkrumah et al. (2016). Zoto and Berisha (2016) analyzed the short-term and long-term impact of the fiscal deficit on economic growth in Albania for the period 1993-2014, using the Cointegration test and multiple regression, the results showed that the fiscal deficit harms economic growth. Todorova (2019) using econometric and comparative analysis between Bulgaria and other new Member States of the European Union (Cyprus, Czech 
Republic, Estonia, Hungary, Latvia, Lithuania, Malta, Poland, Slovakia, Slovenia, Romania, and Croatia, accepted in the EU during 2015) as well as the Balkan countries (Serbia, Turkey, Greece, North Macedonia), examined the effect of the public budget deficit/surplus on real economic growth. Findings from regression analysis showed that a high budget deficit leads to poor economic productivity and low economic growth. The fiscal deficit is negatively correlated with the real economic growth rate. Bokemeier (2015) found a negative correlation between the deficit ratio and economic growth, for the period from 1996 to 2012, for the eight selected European Union Member States in Central and Eastern Europe, which joined the European Union in 2004, this effect shows that it is stronger after EU accession than before.

Tung (2018) examined the effect of fiscal deficit on economic growth in Vietnam, applying the Error Correction model to the 2003-2016 quarterly data. Empirical results showed that the fiscal deficit harmed economic growth in both the short and long term. Moreover, the correlation analysis also noted that the fiscal deficit also has a damaging effect on several macro-variables in the econometric model including private investment, foreign direct investment, and net exports. Goher et al. (2012) include timeseries considering the period 1978-2009, to investigate the influence of fiscal deficit on economic growth in Pakistan, applying regression analysis, the findings showed the adverse impact of fiscal deficit on economic growth. Nkrumah et al. (2016), used the Autoregressive Distributed Lag (ARDL) approach with trend analysis to assess the relationship between Ghana's fiscal deficit and economic growth from 2000 to 2015 with quarterly data. Econometric results showed a significant adverse effect of budget deficits on economic growth. Thus, a 100 percent increase in fiscal deficit, eventually, would lead to a 3 percent decline in real GDP, keeping all other factors constant.

Consistent with the Ricardian view, the neutral effect of fiscal deficit on economic growth was shown by some of the empirical studies: Andoni and Osmani (2017); Ocran (2011); Boldeanu and Ion (2015); Velnampy and Achchuthan (2013); and Wosowei (2013).

Andoni and Osmani (2017) assessed the association between inflation, growth, and fiscal deficits in Albania, using secondary data for the years 1993-2015. Applying the ARDL model, their results showed a negative relationship between inflation and growth, a positive relationship between inflation and deficit, but we did not find any relationship between fiscal deficit and growth. Ocran (2011) examined the effect of fiscal policy variables on economic growth in South Africa during the period 1990-2004. According to Ocran (2011), deficit size does not have any significant impact on growth outcomes. The econometric results of Boldeanu and lon (2015) for the founding countries of the European Union in the period 2000-2011, showed that the fiscal deficit does not have any significant impact on economic growth in these developed countries. Velnampy and Achchuthan (2013) for the period 1970-2010 analyzed the impact of the fiscal deficit on economic growth from the perspective of Sri Lanka. The results revealed that there is no 
significant impact of the fiscal deficit on economic growth. Additionally, there is no significant link between fiscal deficit and economic growth in Sri Lanka's economic outlook. Wosowei (2013) used the OLS model in estimating the relationship between fiscal deficits and macroeconomic performance during the period 1980-2010. Empirical findings showed that fiscal deficits in terms of their negative coefficients, did not significantly affect macroeconomic output within the study period, and that fiscal deficits do not contribute significantly to the overall performance of the economy. The result also shows a bilateral causal relationship between government deficit and GDP, government tax, and unemployment, while there is an independent relationship between government deficit and government spending and inflation.

\section{RESEARCH METHODOLOGY AND DATA ANALYSIS}

A methodology consisting of secondary data for transition countries in Southeast Europe (SEE6) was used to conduct this study. The countries in question are Albania, Bosnia and Herzegovina, Kosovo, North Macedonia, Montenegro, and Serbia. The World Bank and the International Monetary Fund provided the unbalanced panel data. This material will use annual data for a period of 15 years (2005-2019) on GDP, fiscal deficit, public debt, foreign direct investment, trade opening (exports+imports), inflation rate, unemployment, and the real interest rate. The table below shows the definition and description of the selected variables.

Table 1: Data Definition and Description (Source: Authors' specification)

\begin{tabular}{lll}
\hline \multicolumn{1}{c}{ Abbreviations } & Defining variables & \multicolumn{1}{c}{ Indicators expressed in \% } \\
\hline GDP_Growth & Gross domestic product growth & Annual GDP growth rate (\%) \\
\hline FD_GDPrate & Fiscal Deficit to GDP & Annual FD to GDP rate (\%) \\
\hline PD_GDPrate & Public debt to GDP & Annual PD to GDP rate (\%) \\
\hline FDI_GDPrate & Foreign direct investment to GDP & Annual FDI to GDP rate (\%) \\
\hline EXP_GDPrate & Export to GDP & Annual EXP to GDP rate (\%) \\
\hline IMP_GDPrate & Import to GDP & Annual IMP to GDP rate (\%) \\
\hline INF_rate & Inflation rate & Annual INF rate (\%) \\
\hline EMP_rate & Employment rates & Annual EMP rate (\%) \\
\hline RI_rate & Real interest rate & Annual RI rate (\%) \\
\hline
\end{tabular}


To analyze the links between the fiscal deficit and other independent variables in economic growth, two models were used in this study: Fixed effect and Dynamic Linear Regression. The fixed-effects are a statistical model in which the model parameters are fixed or nonrandom quantities. In a fixed-effects, each group average is a group-specific fixed amount. The fixed-effects (FE) are defined as

$\mathrm{GDP}_{\mathrm{it}}=\alpha_{\mathrm{i}}+\beta_{1} \mathrm{X}_{\mathrm{it}}+\varepsilon_{\mathrm{it}}$

Based on the above identified variables, the equation is specified as follows:

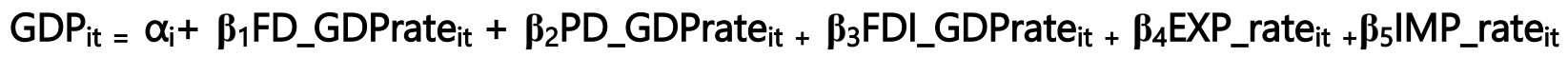

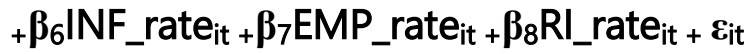

$\alpha_{i}(i=1 \ldots n)$ is the intercept for each country

GDP $_{\text {it: }}$ is a Gross domestic product, $\mathrm{i}=$ country, and $\mathrm{t}=2005-2019$

$X$ it: is a vector of independent variables (fiscal deficit, public debt, foreign direct investment, export, import, inflation rate, employment rate, and real interest rate)

$\boldsymbol{\beta}_{\mathrm{s}:}$ are the coefficients of the independent variables

$\varepsilon_{\text {it: }}$ residual error estimation variable in period $t$

The general dynamic linear model can be written with the help of the observation equation and the model equation such as

$Y_{t}=F_{t}^{\top} \theta_{t}+v_{t}, \quad v_{t, \sim} N\left(0, V_{t}\right)$

$\theta_{\mathrm{t}}=\mathrm{G}_{\mathrm{t}} \theta_{\mathrm{t}-1}+\omega_{\mathrm{t}}, \quad \omega_{\mathrm{t}} \sim \mathrm{N}\left(0, \mathrm{~W}_{\mathrm{t}}\right)$

$F_{t}^{\top}$ is a row in the design matrix representing independent variables affecting $Y_{t}$.

$\mathrm{G}$ is the evolution matrix, capturing deterministic changes to $\theta$, where $\theta_{\mathrm{t}} \approx \mathrm{G} \theta_{\mathrm{t}-1}$.

$\mathrm{V}$ is the observational variant, $\operatorname{Var}(\varepsilon)$ in ordinary least squares.

$W$ is the evolution variance matrix, capturing random changes to $\theta$, where $\theta t=G \theta t-1+$ $\mathrm{wt}$, wt $\sim \mathrm{N}(0, \mathrm{~W})$. The two parameters $\mathrm{G}$ and $\mathrm{W}$ make a linear model dynamic.

Based on the above-identified variables, the equation is specified as follows:

$\mathrm{GDP}_{\mathrm{t}}=\mathrm{FD} \_\mathrm{GDPrate} \theta_{\mathrm{t}}+$ PD_GDPrate $\theta_{\mathrm{t}}+\mathrm{FDI} \mathrm{FDPrate}_{\mathrm{t}+} \mathrm{EXP}_{-}$rate $\boldsymbol{\theta}_{\mathrm{t}}+\mathrm{IMP}$ rate $\theta_{\mathrm{t}+}$ INF_rate $\boldsymbol{\theta}_{\mathrm{t}}+$ $E M P \_r a t e \theta_{t}+R_{-}$rate $\theta_{t}+v_{t}$ 


\section{EMPIRICAL FINDINGS AND DATA PRESENTATION}

Panel data were evaluated using the fixed-effect model and the dynamic linear regression model through Stata software. The findings of the study show a positive impact of the fiscal deficit on economic and statistically significant growth.

\section{Summary Statistics}

Descriptive statistics for the variables used in the study are presented in Table 2. From this table, we can see that the average GDP growth rate in the SEE6 economy has been around 3.3 percent, with a minimum growth rate of -5.7 and a maximum growth rate of 8.8 percent, as well as a standard deviation of 2.50 percent. Alternatively, the ratio of deficit to GDP has an average of -2.27 percent, with a standard deviation of 2.75 percent, while the minimum values of -7.9 percent, to 7.3 percent maximum.

Table 2: Summary Statistics (Source: Authors' calculations)

\begin{tabular}{|l|l|l|l|l|l|l|}
\hline & \multicolumn{1}{|c|}{ Obs } & \multicolumn{1}{c|}{ Min } & \multicolumn{1}{c|}{ Max } & \multicolumn{1}{c|}{ Mean } & \multicolumn{1}{c|}{$\begin{array}{l}\text { Standard } \\
\text { Deviation }\end{array}$} & Variance \\
\hline GDP_Growth & 90 & -5.7 & 8.8 & 3.29 & 2.50 & 6.26 \\
\hline FD_GDPrate & 90 & -7.9 & 7.3 & -2.27 & 2.75 & 7.61 \\
\hline PD_GDPrat & 90 & 5.2 & 79.3 & 41.48 & 19.64 & 385.8 \\
\hline FDI_GDPrate & 90 & 0 & 37.2 & 6.81 & 5.57 & 31.07 \\
\hline EXP_GDPrate & 90 & 11.2 & 62.2 & 34.55 & 10.29 & 105.99 \\
\hline IMP_GDPrate & 90 & 39.6 & 92.8 & 56.5 & 9.28 & 86.23 \\
\hline INF_rate & 90 & -2.4 & 16.3 & 2.82 & 3.25 & 10.57 \\
\hline EMP_rate & 90 & 22.4 & 53.4 & 38.66 & 7.42 & 55.11 \\
\hline RI_rate & 90 & -9.7 & 17.8 & 5.28 & 4.55 & 20.7 \\
\hline
\end{tabular}

Analysis of Correlation

The purpose of correlation analysis is to reveal the significant association between independent and dependent factors. Table 3 presents the outcomes of the correlation analysis. 
Table 3: Correlation Analysis (Source: Authors' calculations)

\begin{tabular}{|c|c|c|c|c|c|c|c|c|c|}
\hline & $\begin{array}{l}U^{\prime} \\
0^{\prime} \\
\text { ज̂ }\end{array}$ & 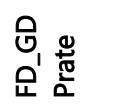 & 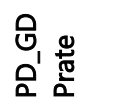 & 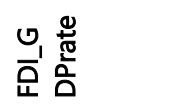 & 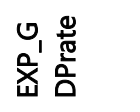 & 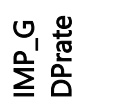 & $\begin{array}{l}\frac{\tilde{J}_{0}}{\omega_{1}} \\
\underline{\underline{u}} 。\end{array}$ & 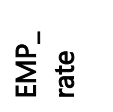 & 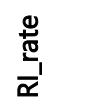 \\
\hline GDP_Growth & 1 & & & & & & & & \\
\hline FD_GDPrate & 0.5009 & 1 & & & & & & & \\
\hline PD_GDPrate & -0.2118 & -0.3964 & 1 & & & & & & \\
\hline FDI_GDPrate & -0.0666 & -0.0543 & 0.1357 & 1 & & & & & \\
\hline EXP_GDPrate & -0.1352 & -0.0035 & 0.3588 & -0.0092 & 1 & & & & \\
\hline IMP_GDPrate & 0.2208 & 0.2324 & -0.1227 & 0.3149 & 0.6004 & 1 & & & \\
\hline INF_rate & 0.1992 & 0.1992 & -0.0632 & 0.1000 & -0.083 & -0.0284 & 1 & & \\
\hline$E M P_{-}$rate & -0.0803 & -0.2878 & -0.2878 & 0.1385 & 0.4427 & -0.0449 & 0.1228 & 1 & \\
\hline RI_rate & -0.1006 & -0.2309 & -0.1486 & 0.0252 & -0.3861 & -0.1414 & -0.5415 & -0.3206 & 1 \\
\hline
\end{tabular}

Table 3 reveals that the highest correlation (.500) is between the fiscal deficit and GDP growth, confirming an important positive association between the fiscal deficit and GDP growth rates. The second variable that shows a positive association in economic growth is the ratio of imports to GDP with a coefficient of (.220), followed by (.199) between the inflation rate and GDP growth. Referring to Table 3, other variables, the ratio of the public debt of $(-.211)$ and the ratio of export (-.135) to GDP have shown a negative impact on economic growth. The lowest correlation was found to foreign direct investment (-.066) and the employment rate (-.080) to the economic growth rate.

Regression Outcomes

The results obtained from the fixed-effect data show that $\mathrm{R}$-squared is equal to .433 , indicating that the dependent variable is explained at the level of or 43.3 percent of the independent variables. Also in the fixed-effect examination, the F-test is equal to 9.66, which shows that all constants are less than $<10$, which gives us indications that the model is appropriate and adequate. Whereas in the second model dynamic linear regression is applied one-step results, in lag (1) as well as for the analysis of autocorrelation the art test (2) chi2 $=182.7$ was used, with the value of $\mathrm{P}<0.01$, which proves stability and sustainability of the model. Lastly, the Sergan test of overidentifying restrictions was applied, and the results indicate that overidentifying restrictions are valid. 
Table 4: Regression Results (Source: Authors' calculations)

\begin{tabular}{|c|c|c|c|c|}
\hline \multirow[b]{2}{*}{ Variable } & \multirow{2}{*}{$\begin{array}{c}\text { Fixed Effect } \\
\text { Coeff }\end{array}$} & \multirow[b]{2}{*}{ P-Value } & \multicolumn{2}{|c|}{ Dynamic Linear Regression } \\
\hline & & & Coeff & P-Value \\
\hline Constant & -2.317647 & 0.532 & -2.906468 & 0.400 \\
\hline FD_GDPrate & 0.424957 & 0.000 & 0.6048551 & 0.000 \\
\hline PD_GDPrate & 0.0092271 & 0.762 & 0.0619469 & 0.038 \\
\hline FDI_GDPrate & -0.1760331 & 0.000 & -0.1988107 & 0.000 \\
\hline EXP_GDPrate & -0.167397 & 0.004 & -0.2549333 & 0.000 \\
\hline IMP_GDPrate & 0.1967038 & 0.000 & 0.2738306 & 0.000 \\
\hline INF_rate & 0.0426554 & 0.656 & 0.1065862 & 0.259 \\
\hline EMP_rate & 0.0565143 & 0.511 & -0.0030416 & 0.973 \\
\hline RI_rate & -0.0470903 & 0.551 & -0.0938537 & 0.345 \\
\hline Observation & 90 & & 90 & \\
\hline $\mathrm{R}$ & 0.5041 & & "-" & \\
\hline R-squared & 0.4336 & & "-" & \\
\hline F-test & 9.66 & & "-" & \\
\hline Chi 2 & "-" & & 182.7 & $\mathrm{P}<0.01$ \\
\hline Sergan Test & "-" & & 88.932 & $P=0.1299$ \\
\hline Model & Fe model & & Dynamic panel & \\
\hline
\end{tabular}

Dependent variable: GDP growth

Table 4 reports the regression outcomes using the fixed effect estimation and dynamic linear regression. The outcomes generated by both models show a positive impact of the fiscal deficit on economic growth and as well confirm the hypothesis that there is a positive association between the fiscal deficit and GDP growth. The findings of the study are consistent with the Keynesian view that the fiscal deficit positively affects economic growth. The study displays similar outcomes to previous works by different authors, such as Okelo et al. (2013), to investigate the association between fiscal deficits and economic growth using the OLS method and secondary time series data for a period of 38 years (1970-2007), argued positive associations between fiscal deficit and economic growth. Furthermore, Kryeziu and Durguti (2019), Ahmad et al. (2020), Kryeziu and Hoxha (2021) showed that the fiscal deficit has a confident influence on GDP.

The outcomes show that the impact of imports is positive $(P<0.01)$ in both models, which is consistent with the study Hamdan (2016), the study analyzes the effect of exports and imports on economic growth in Arab countries during the period 1995 to 2013. The study found that imports have a positive effect on economic growth. Public debt $(P=0.762)$ in the Fixed effect model and $(P=0.038)$ in the Dynamic Linear Regression model, but with an insignificant value, also showed a positive impact on 
economic growth. This result is consistent with Owusu-Nantwi and Erickson (2016) study investigated the long-term and short-term relationship between public debt and economic growth for the period 1970 to 2012. The results revealed a positive and significant long-term relationship between real GDP growth and public debt, showing that public debt contributed to economic growth in Ghana. In the short run, there is a two-way relationship between public debt and economic growth, which means that public debt causes economic growth and vice versa. Foreign direct investment $(P<0.01)$ in both models showed a negative impact. This result shows that the expansion of the level of foreign direct investment harms economic growth. The outcomes of this analysis are consistent with the results of Saqib et al. (2013) who researched the relationship between foreign direct investment and Pakistan's economic growth, from 1981 to 2010. They found that Pakistan's economic performance is negatively affected by foreign direct investment. The explanatory variable exports to GDP applied in the model, based on the results achieved show a negative impact $(P=0.004)$ on the fixed-effect and $(P<0.01)$ on the Dynamic Linear Regression. This outcome shows that the increase in export levels is associated with a negative impact on economic growth, and this result is also consistent with the study of Durguti et al. (2020) which analyzes the assessment of economic indicators for the Western Balkans for the period 2001-2017 and found that exports have a negative impact and do not support economic growth. For the other additional variables, inflation rate, employment rate, and real interest rate applied in the Fixed effect and the Dynamic Linear Regression, the result does not show any significant impact on economic growth.

\section{CONCLUSION}

The aim of this research strove to examine the relationship of the fiscal deficit on economic growth in the transition countries of Southeastern Europe. Using data from 2005 to 2019, the study uses the fixed effects model and the dynamic linear regression model to investigate the impact of fiscal deficit and other explanatory variables (public debt, foreign direct investment, trade opening, inflation rate, employment rate, and real interest rate) in economic growth. The study provides an empirical test on the relationship between the budget deficit and economic growth for the transition countries of Southeast Europe, analyzed from two aspects: a theoretical and empirical perspective. The results from the application of both models reveal that there is a positive and significant relationship between fiscal deficit and economic growth, supporting the Keynesian theory, that the fiscal deficit produces positive impacts on the economy as a whole promoting economic growth.

This resulting study that public debt to GDP, foreign direct investment in GDP, exports, and imports in GDP have a significant effect on economic growth. Findings have shown that public debt and imports have a positive impact on economic growth, unlike 
exports and foreign direct investment, which showed a negative impact on economic growth. Furthermore, for other additional variables, inflation rate, employment rate, and real interest rate, the study result does not show any significant impact on economic growth. This study contributes to the policy dilemma by examining the impact of the fiscal deficit on economic growth for the transition countries of Southeast Europe. Therefore, the empirical results obtained in this study will serve as an extension and supplement to the already existing literature and will be important for policymakers in structuring and using effective fiscal policies in the economy.

Finally, although this study has provided ample evidence in support of the proposition that the fiscal deficit has a positive relationship with economic growth for the transition countries of Southeast Europe, it is nevertheless necessary that the level of deficits should be controlled by governments, because high fiscal deficit, eventually, can harm economic growth and other macroeconomic variables. Thus, the government must move toward the fiscal deficit to the point where the fiscal deficit positively affects economic growth. 


\section{REFERENCES}

1. Abdullah, S. M., Azad, A. K., \& Siddiqua, S. (2018). Budget deficit and growth: in search of ceiling for Bangladesh. Business and Economic Horizons, 14(4), 743765. https://doi.org/10.15208/beh.2018.52

2. Adam, C., \& Bevan, D. (2005). Fiscal deficits and growth in developing countries. Journal of Public Economics, 89(4), 571-597. https://doi.org/10.1016/j.jpubeco.2004.02.006

3. Ahmad Bhari, A. A., Lau, W.-Y. Aslam, M., \& Yip, T.-M. (2020). THE NEXUS BETWEEN FISCAL DEFICIT AND ECONOMIC GROWTH IN MALAYSIA. Journal of Southeast Asian Studies, 25(1), 79-94. https://doi.org/10.22452/jati.vol25no1.5

4. Akosah, N. K. (2013). The Threshold Effect of Budget Deficits on Economic Growth in Ghana: An Empirical Analysis. SSRN Electronic Journal. https://doi.org/10.2139/ssrn.2289523

5. Andoni, M., \& Osmani, M. (2017). Assessment of Relationship Between Inflation, Growth and Fiscal Deficit in Albania-An Econometric Approach. European Scientific Journal, ESJ, 13(13), 137. https://doi.org/10.19044/esj.2017.v13n13p137

6. Barro, R. J. (1989). The Ricardian Approach to Budget Deficits. Journal of Economic Perspectives, 3(2), 37-54. https://doi.org/10.1257/jep.3.2.37

7. Bernheim, B. D. (1989). A Neoclassical Perspective on Budget Deficits. Journal of Economic Perspectives, 3(2), 55-72. https://doi.org/10.1257/jep.3.2.55

8. Bökemeier, B. (2015). Economic growth and the public deficit in EU member states in Central and Eastern Europe. Romanian Journal of Fiscal Policy (RJFP), 6(1), 47-53. http://hdl.handle.net/10419/168629

9. Boldeanu F. T. and Ion M. S. (2015). The Impact of Fiscal Policy on Economic Growth in the Founding Countries of the European Union. RevistaEconomică, 6(7), 207-2017.

http://economice.ulbsibiu.ro/revista.economica/archive/67502boldeanu\&tache\&i on.pdf

10. Dritsakis, N., \&Stamatiou, P. (2016). Budget Deficit, Economic Growth and FDI in the Baltics: A Cross-Section Dependence Panel Approach. Journal of Research in Humanities and Social Science, 4(12), 65-76.

https://www.academia.edu/30716319/Budget Deficit Economic Growth and FDI in the Baltics A Cross Section Dependence Panel Approach

11. Durguti, E., Gashi, E., Kunoviku-Demiri, F., \& Mehmeti, M. (2020). Evaluation of Economic Indicators for Western Balkans Countries: Policy Recommendations for the Financial and Economic Growth. International Journal of Finance \& Banking Studies,9(1), 36-46. https://doi.org/10.20525/ijfbs.v9i1.652

12. Eigbiremolen, G. time, Ezema, N. J., \& Orji, A. (2015). Dynamics of Budget Deficit and Macroeconomic Fundamentals: Further Evidence from Nigeria. International 
Journal of Academic Research in Business and Social Sciences, 5(5). https://doi.org/10.6007/ijarbss/v5-i5/1590

13. Goher, F. Mehboob, A., \&Rehman, W. (2012). Consequential Effects of Budget Deficit on Economic Growth of Pakistan. International Journal of Business and Social Science, 3, 203-208. https://doi.org/Impact of Budget Deficit on Economic Growth (An Empirical Study of PAKISTAN) (ijbssnet.com)

14. Hamdan, B. S. (2016). The Effect of Exports and Imports on Economic Growth in the Arab Countries: A Panel Data Approach. Journal of Economics Bibliography, 3(1), 100-107. https://doi.org/kspjournals.org/index.php/JEB/article/view/600

15. Hussain, M., \& Haque, M. (2017). Fiscal Deficit and Its Impact on Economic Growth: Evidence from Bangladesh. Economies, 5(4), 37. https://doi.org/10.3390/economies5040037

16. Kofi Ocran, M. (2011). Fiscal policy and economic growth in South Africa. Journal of Economic Studies, 38(5), 604-618. https://doi.org/10.1108/01443581111161841

17. Kryeziu, N., \& Durguti, E. (2019). The Impact of Fiscal Deficit on Inflation Rate Empirical Evidence Case of Eurozone. Journal of Finance \& Banking Studies 8(1), 8(1), 1-9. https://doi.org/10.20525/ijfbs.v8i1.297

18. Kryeziu, N., \& Hoxha, E. (2021). Fiscal Deficit and its Effects on Economic Growth: Empirical evidence Nexhat. International Journal of Finance \& Banking Studies, 10(1), 62-70. https://doi.org/DOl:10.20525/ijfbs.v10i1.1064

19. Mohanty, R. K. (2012). Fiscal Deficit-Economic Growth Nexus in India: A Cointegration Analysis. New Delhi: Center for Economic Studies \& Planning, School of Social Sciences Jawaharlal Nehru University. https://doi.org/DOl:10.17010/aijer/2019/v8i4/148068

20. Navaratnam, R., \&Mayandy, K. (2016). The causal nexus between fiscal deficit and economic growth. International Journal for Innovation Education and Research, 4(8), 1-19. https://doi.org/10.31686/ijier.vol4.iss8.575

21. Nkrumah, K. O., Orkoh, E., \& Owusu, A. M. (2016). EXPLORING THE BUDGET DEFICIT-ECONOMIC GROWTH NEXUS: NEW EVIDENCE FROM GHANA. Journal for the Advancement of Developing Economies, 5(1), 30-43. https://doi.org/10.13014/k2nz85vx

22. Okelo, S. O., Momanyi, G., Othuon, L., \& Fredrick, O. A. (2013). The Relationship between Fiscal Deficits and Economic Growth in Kenya: An Empirical Investigation. Greener Journal of Social Sciences, 3(6), 306-323. https://doi.org/10.15580/gjss.2013.6.051113603

23. Onwioduokit, E. A., \&lnam, U. S. (2018). Budget Deficit and Economic Growth in Liberia: An Empirical Investigation. American Journal of Humanities and Social Sciences Research (AJHSSR), 2(6), 68-78. http://www.ajhssr.com/wpcontent/uploads/2018/06/F18266878.pdf 
24. Owusu-Nantwi, V., \& Erickson, C. (2016). Public Debt and Economic Growth in Ghana. African Development Review, 28(1), 116-126. https://doi.org/10.1111/1467-8268.12174

25. Ramu, M. R., \&Gayithri, K. (2017). Fiscal Deficit and Economic Growth Relationship in India: A Time Series Econometric Analysis. Current Issues in Economics and Finance, 19-36. https://doi.org/10.1007/978-981-10-5810-3 2

26. Saqib, N., Masnoon, M., \& Rafique, N. (2013). Impact of Foreign Direct Investment on Economic Growth of Pakistan. Journal of Advances in Management and Applied Economics, 3(1), 35-45. https://doi.org/papers.ssrn.com/sol3/papers.cfm?abstract_id=2207626

27. Taylor, L., Proano, C. R., de Carvalho, L., \& Barbosa, N. (2012). Fiscal deficits, economic growth, and government debt in the USA. Cambridge Journal of Economics, 36(1), 189-204. https://doi.org/10.1093/cje/ber041

28. Thornton, D. L. (1990). Do Government Deficits Matter? Review, 72(5), 25-39. https://doi.org/10.20955/r.72.25-39

29. Todorova, T. P. (2019). Government Budget Balance and Economic Growth. Journal of International Scientific Publications, 13, 114-127. https://www.scientific-publications.net/get/1000037/1570290990457887.pdf

30. Tung, L. T. (2018). The effect of fiscal deficit on economic growth in an emerging economy: Evidence from Vietnam. Journal of International Studies, 11(3), 191203. https://doi.org/10.14254/2071-8330.2018/11-3/16

31. Velnampy, T., \&Achchuthan, S. (2013). Fiscal Deficit and Economic Growth: A Study on Sri Lankan Economic Perspective. The International Institute for Science, Technology, and Education (IISTE), 3(3), 166-174. https://www.academia.edu/3174017

32. Wosowei, E. (2013). Fiscal Deficits and Macroeconomic Aggregates in Nigeria. Kuwait Chapter of Arabian Journal of Business and Management Review, 2(9), $72-$ 82. https://doi.org/10.12816/0001235

33. Zoto, O., \& Berisha, M. (2016). Budget Deficit and Economic Growth In Albania. International Journal of Engineering Sciences \& Research Technology, 5(9), 333340. https://doi.org/10.5281/zenodo.154199 